\title{
Dropping out of high school in Cyprus: do parents and the family matter?
}

\section{Loizos Symeou, Raquel-Amaya Martínez-González \& Lucía Álvarez-Blanco}

To cite this article: Loizos Symeou, Raquel-Amaya Martínez-González \& Lucía Álvarez-Blanco (2014) Dropping out of high school in Cyprus: do parents and the family matter?, International Journal of Adolescence and Youth, 19:1, 113-131, DOI: 10.1080/02673843.2012.717899

To link to this article: http://dx.doi.org/10.1080/02673843.2012.717899

(c) 2012 Taylor \& Francis

曲 Published online: 11 Sep 2012.

Submit your article to this journal $\sqrt{\top}$

Џll Article views: 428

Q View related articles $\longleftarrow$

View Crossmark data 


\title{
Dropping out of high school in Cyprus: do parents and the family matter?
}

\author{
Loizos Symeou $^{\mathrm{a} *}$, Raquel-Amaya Martínez-González ${ }^{\mathrm{b}}$ and Lucía Álvarez-Blanco ${ }^{\mathrm{b}}$ \\ ${ }^{a}$ Department of Education Sciences, European University Cyprus, Nicosia, Cyprus; ${ }^{b}$ Department of \\ Education Sciences, Oviedo University, Oviedo, Spain
}

(Received 1 May 2012; final version received 31 July 2012)

\begin{abstract}
This paper presents a comparison of family circumstances, aspirations and school involvement of parents in Cyprus whose children were at risk of dropping out of high school and parents whose children were not at risk. The data were collected through a questionnaire survey constructed within the framework of the European project DropOut Open Door. The results showed a broad range of differences in the resources, expectations, perceptions and practices of pupils' families who are at risk of dropping out of school and those who are not. The findings illustrate the necessity for schools to identify families' different circumstances and needs and provide them, especially those with pupils at risk, with facilities, support and training for enhancing their children's development and school success through everyday family practices.
\end{abstract}

Keywords: drop-out; high school; Cyprus; families

\section{Introduction}

The increasing personal and social cost of dropping out of school is stimulating educational decision-makers to look for educational measures to prevent it (European Commission Directorate General for Education \& Culture, 2005; National Research Council, 2001). Some of these measures are related to promoting children's development and pupils' retention. International studies and reviews on this topic stress the difficulty of identifying the causes of this phenomenon (Fredricks, Blumenfeld, \& Paris, 2004) and suggest a variety of school and non-school-related factors that might explain it (Bull \& Garrett, 1989; Bull, Salyer, \& Montgomery, 1990; Coley, 1995; Ekstrom, Goertz, Pollack, \& Rock, 1986; Helge, 1990; Rumberger, 1987).

Following Bronfenbrenner's (1979) ecology of human development model, Rumberger (2001) supports the idea that dropping out of school is influenced by an array of both proximal and distant factors related, respectively, to the individual pupil and to the pupil's context; namely the family, the school, the local community, the peers, the mass media, and the information and communication technologies.

School factors that might push pupils to drop-out very often relate to occasions when they find themselves in conflict with individual teachers or administrators; this frequently ends up with being expelled from school (Comerford \& Jacobson, 1987; Lan \& Lanthier, 2003). Similarly, repeating a course as well as missing lessons and truancy are factors that negatively affect the possibility of graduating, which might lead a pupil to drop-out from

\footnotetext{
*Corresponding author. Email: L.Symeou@euc.ac.cy
} 
school (Janosz, Archambault, Morizot, \& Pagani, 2008; Widmann \& Hoisden, 1988). The lack of vocational or non-college curriculum in schools might also lead to pupils' failure and eventual drop-out. This is more clearly seen in those belonging to minority groups with low achievement (Bishop, 1988; Schultz, Tules, Rice, Brauer, \& Harvey, 1986; Weber \& Sechler, 1988). Intolerance of school officials for cultural and ethnic diversity can also have an impact on a pupil's development and decision to remain at school (Lee \& Burkam, 2003; Wheelock, 1986).

Non-school-related factors that may cause pupils' drop-out of school are closely associated with both the characteristics of the pupils themselves (Anderson, Whipple, \& Jimerson, 2002) and their environment outside the school setting, such as the family and their neighbourhoods (South, Baumer, \& Lutz, 2003).

Pupils who come from homes where education is not valued or whose parents have no involvement in their development and education frequently drop-out (Barr \& Knowles, 1986; Coleman, 1988; Rumberger, 2004). Families facing unresolved conflicts, sexual, physical and/or psychological abuse, or parental drug misuse, may place a pupil at a higher risk of dropping out.

Female pupils who become pregnant frequently drop-out from school for a variety of reasons, either before or after the child's birth (Ediger, 1987; Hartford Public Schools, 1987). Pupils who break the law or consume drugs are also likely to drop-out (Mensch \& Kendel, 1988). Missing school due to chronic health problems, as well as due to truancy, puts pupils at risk of leaving school permanently (Levy, 1987; Raffe, 1986). In addition, pupils with peers who have dropped out themselves are often persuaded to do the same (Dunham \& Alpert, 1987). This occurs more often when both pupils and peers are lawbreakers. Pupils may also drop-out if there is no group in school to which they can relate to (Bull \& Garrett, 1989). Absenteeism and discipline problems, the most common indicators of lack of pupils' involvement regarding schooling, are both associated with dropping out (Carbonaro, 1998; Ekstrom et al., 1986; Goldschmidt \& Wang, 1999; Rumberger, 1995; Rumberger \& Larson, 1998; Swanson \& Schneider, 1999; Wehlage \& Rutter, 1986).

During the evolutionary stage of adolescence, the risk of school failure is higher than in other developmental stages, and is associated with poor marks, reduced social adaptation and low self-esteem (Kagan, 1990). As suggested by Bourdieu (1998), Coleman et al. (1966) and Coleman $(1988,1997)$, the family and the school, as socialising agents, are called to control this risk. Nonetheless, parents do not always feel competent enough to cope with their teenagers' needs and demands. The affective, social, motivational and academic changes of adolescents may eventually make parents feel disorientation, frustration, guilt, or failure in the performance of their parental role (Smetana \& Daddis, 2002; Steinberg, 2001; Steinberg \& Silk, 2002). This leads parents to frequently demand educational guidelines to deal with their adolescents (Martínez-González, Pérez-Herrero, Álvarez-Blanco, \& García-González, 2009).

Families who belong to lower social strata seem to need more educational guidance than others (Coleman, 1997; Collins \& Laursen, 2004; Chen \& Kaplan, 2003; Granic, Dishion, \& Hollesntein, 2003; Lareau, 2000; Marjoribanks, 2004; Smetana \& Daddis, 2002; Symeou, 2010). Similarly, parental efficacy and 'the curriculum of the home', understood as family attributions, expectations, beliefs, and ability to help their children, among other issues, seem to influence families' involvement in their children's development and the latter's school performance (Deslandes, 2001; Redding, 2000; Symeou, 2005). In keeping with Bourdieu (1998; Bourdieu, \& Passeron, 1990), his analysis points to the importance of class and class cultures in mediating children's and parents' negotiations in the schooling system. His theory claims that social class inequalities in educational attainment lie in the 
social distribution of cultural capital. Thus, educational differences reproduction leads to social differences reproduction (Bourdieu, 1998; Bourdieu \& Passeron, 1990).

A primary purpose of this paper is to approach the drop-out problem from a perspective that has not been much considered in past studies - that of the families. These efforts were designed to paint a more in-depth picture of family circumstances, educational practices, aspirations and school involvement of parents whose children are at risk of dropping out of school and those ones whose children are not at risk.

The study was conducted in Cyprus within the framework of the European Project Drop-Out Open-Door (DOOR; Socrates, 112578-CP-1-2003-1-NL-COMENIUS-C21), which investigated the phenomenon of pupils' dropping out of compulsory secondary education in the formative ages of 13-16 years. For the purpose of this European project, 'dropping out' was defined as the situation in which pupils voluntarily give up their studies and the school before the age they are expected to; in this case, according to the Cypriot educational legislation, namely before completing compulsory Gymnasio (lower secondary school).

This study might appear significant for supporting the Greek-Cypriot educational system to find strategies to cope with this social phenomenon, given the comparison performed between parents of children at risk and parents of children not at risk of dropping out of compulsory secondary school. Also, its findings might promote the exchange of ideas, initiatives and experiences related to this drawback in compulsory secondary school internationally, and may suggest to schools, educational leaders and policy-makers effective educational interventions to support families and their children's development.

\section{The Cypriot educational context}

Education is perhaps the greatest achievement of the Cypriot society since the country's independence in 1960. The small population, as well as the lack of natural resources, created a collective determination to stimulate human intellectual development (Persianis, 1981). Education is highly esteemed by the people of Cyprus, especially because it is regarded to lead to better employment, a comparatively higher standard of living, more social mobility and higher socio-economic status. Not surprisingly, in 2011 Cyprus had the sixth highest percentage of young people with highest educational attainment - at least upper secondary - among the 27 country members of the European Union. It was also ranked sixth among the 27 as regards the proportion of the population aged 30-34 with tertiary education, namely $45.8 \%$; this percentage is close to the $46 \%$ target set in the Europe 2020 Strategy (Statistical Service of Cyprus, 2012).

Education in Cyprus, ${ }^{1}$ either state or private, is compulsory up to the age of 15 , and state education is free up to the age of 18. There is one year of compulsory pre-primary school, followed by six compulsory years of primary education for children from approximately six to 12-years-old. Secondary education extends over to six years and is divided into two cycles: the lower secondary school (Gymnasio), which is compulsory for children of the 12-14 age group; and the upper secondary school, which comprises the final three years of secondary education for the 15-18 age group. It is offered either in an Eniaio (Comprehensive) Lyceum or in a Technical/Vocational School. State schools are all mixed sex and, until very recently, highly homogeneous in terms of religion (Christian Greek-Orthodox) and ethnicity (Greek-Cypriot). The language of instruction is Greek.

As a Cyprus state-wide survey shows, about $2 \%$ of pupils of compulsory lower secondary education drop-out every year, the majority of whom do so in the first year of 
their secondary studies (Cyprus Pedagogical Institute, 2002). It appears that it is more boys and pupils from rural areas, and also those who belong to low to average income family strata that predominantly drop-out. According to the same survey, the majority of the parents of drop-out pupils are drop-outs themselves.

Despite the low percentage of pupils dropping out of compulsory education, it seems that the phenomenon outbreaks among upper secondary education pupils. The Labour Force Survey of EuroStat (2005) shows that $18.1 \%$, or two out of every 11 pupils, drop-out from the Lyceum and the Technical School; this summing up to approximately 14,000 teenagers in the last 10 years. This figure has been considered quite disturbing considering the size of the country and the fact that the numbers are comparatively higher than the average rate of the European Union countries. Of similar concern is the number of early school-leavers (i.e. the percentage of the population aged 18-24 with at most lower secondary education qualification and not in further education or training), which, even though in 2011 was lower than the EU-27 average (13.5\%), is still considered high (11.2\%) (Statistical Service of Cyprus, 2012).

The only educational pathway available to pupils of ages 14-16 who drop-out from school in Cyprus is to enter the Apprenticeship Scheme, which is administered by the Ministry of Labour and Social Insurance, although the syllabus is provided by the Ministry of Education. Drop-outs can also attend evening classes run by the Ministry of Education and Culture, and obtain the school-leaving certificate awarded at the end of the upper secondary school level.

\section{Method}

\section{Objective and dimensions analysed}

The main goal of this study was to gain an insight into four dimensions of family implication in their children's development, which might relate to children's school achievement and the risk of dropping out: children's cultural resources and habits at home and in the community; parental involvement in their children's school progress; parental academic expectations for their children; and parental contacts with the school.

The main hypothesis under research is that parents of children at risk of dropping out of school are likely to be less literate and to face more difficulties to get involved in their children's development than their counterparts are; this having an influence on children's school success or the risk of dropping out.

\section{Procedure}

In selecting the family target group, three Gymnasia across Cyprus were chosen. In order to avoid selection bias, school variables that might relate to the drop-out phenomenon were taken into consideration, namely: the school location (one urban school, one semiurban school and one rural school were included); their size in terms of number of pupils (the schools selected included one large school, one average school and one small school, according to national figures); their socio-economic status catchments (based on national and school figures, one school that served families of upper class, one school that served predominantly middle-class families and one school located in a lower-class catchment area were included); and their percentage of pupils dropping out of compulsory secondary education compared with the national average in the last two years (one school with lower percentage than the national average, one school with larger percentage and one school with a percentage close to the national average took part in the study). 
The sample of the families that participated within each school was classified into two categories: those whose children were at risk of dropping out; and those whose children were not. The criteria set for identifying the families whose children were potential school drop-outs was the combination of the following: children to be low achievers or to have repeated a grade; children to have been often expelled from school; children to have been repeatedly reported for misbehaviour and/or truancy; and children to belong to a family considered indifferent to and detached from the school. Families whose children were not classified as potential drop-outs were randomly selected from the rest of the families whose children attended these three schools.

The procedures followed to select the sample in the participant schools were ethically scrutinised and approved by the Cyprus Pedagogical Institute on behalf of the Ministry of Education and Culture.

\section{Participants}

The final family sample was composed of 70 parents whose children were at risk of dropping out and 123 whose children were not at risk. Parents who responded to the questionnaire were, according to their gender, mostly mothers (75\%); another $1.4 \%$ was female carers/guardians. These findings confirm the traditional expectation that mothers are more involved in their children's development than fathers, which has been extensively proved to be so internationally (Crozier, 2000; Lareau, 2000; Reay, 1998) and locally (Phtiaka, 1998; Symeou, 2002, 2007).

Self-reported parental education showed that $39.1 \%$ of the fathers had low educational background, $48.8 \%$ had reached secondary school level and $12.1 \%$ higher level. For mothers, these figures were $44.8 \%, 48.0 \%$ and $7.1 \%$, respectively.

A significant statistical association was found between the fathers' educational level and the risk of dropping out: those with only low education background have more children at risk than those with higher education level $\left(\chi^{2}=19.976\right.$, degrees of freedom $[\mathrm{df}]=2, p=0.00)$. Similarly, this significant statistical association was found when considering that of the mothers $\left(\chi^{2}=6.788, \mathrm{df}=2, p=0.03\right)$.

These results confirm the aforementioned hypothesis that parents of children at risk of dropping out are likely to be less literate than their counterparts, which may condition the quality of the support they can provide to their children in relation to homework and curricular matters.

\section{Procedure to gather information/research instruments}

In order to gather information from parents/carers/guardians, a questionnaire was constructed with 64 close-ended questions to be answered in a four-point Likert scale ( $1=$ 'I Totally Disagree', $2=$ 'I Disagree', $3=$ 'I Agree' and $4=$ 'I Totally Agree'). A 'no opinion' option was also provided. The questionnaire was delivered to families via their children in order to be completed at home. The Cronbach's alpha of the questionnaire of parents whose children were at risk of dropping out was 0.76 , while that for the questionnaire of parents whose children were not at risk was 0.69 .

\section{Data analysis}

Data collected were analysed with the SPSS package using descriptive measures (frequencies, percentages), as well as contingency tables and $t$-test comparative analysis 
(taking into account the figure that results from subtracting from the at-risk group mean the not-at-risk group mean on the issues considered in the study, i.e. at-risk group mean minus not-at-risk group mean).

\section{Results}

This section describes the results obtained when comparing the perceptions of the families with children at risk of dropping out with those whose children were not at risk on the dimensions analysed in this study.

\section{Children's cultural resources and habits at home and in the community}

This dimension investigated whether pupils were privileged by a series of cultural resources and habits at home and in their community, which might affect their personal development and school achievement. The hypothesis for this dimension was that children at risk of dropping out are less likely to have access to these resources than children who are not at risk, which may be associated with their poor school results.

The descriptive analysis showed that the parents in the sample perceived that the activities practised more by their teenagers - both at risk and not-at-risk - in their leisure time were to watch television $(70.2 \%)$, to go out with friends $(69.5 \%)$ and to play sports $(58.8 \%)$. Reading was the activity less performed compared with others $(17.6 \%)$.

Table 1 shows that a $t$-test significant statistical association was found with more nonat-risk pupils to have a computer at home, to use the Internet there, to go to the library regularly and to read books at their leisure time than their at-risk counterparts. Additionally, the comparison pointed out that more at-risk pupils than non-at-risk ones meet their boy/girlfriend in their leisure time. These findings might suggest that pupils who do not face the possibility of dropping out are more likely to live in a home

Table 1. Pupils' cultural resources.

\begin{tabular}{|c|c|}
\hline Cultural resource & Response $^{\mathrm{a}}$ \\
\hline $\begin{array}{l}\text { My child studies in his/her own } \\
\text { room at home }\end{array}$ & $\begin{array}{l}\text { No significant statistical differences between not-at } \\
\text { risk and at-risk pupils }\end{array}$ \\
\hline $\begin{array}{l}\text { My child uses books to check/consult } \\
\text { his/her homework at home }\end{array}$ & $\begin{array}{l}\text { No significant statistical differences between not-at } \\
\text { risk and at-risk pupils }\end{array}$ \\
\hline $\begin{array}{l}\text { My child has a computer at } \\
\text { home }\end{array}$ & Not-at-risk $>$ at-risk $\left(\chi^{2}=5.652, \mathrm{df}=1, p=0.01\right)$ \\
\hline My child uses the Internet & Not-at-risk $>$ at-risk $\left(\chi^{2}=8.614, \mathrm{df}=1, p=0.00\right)$ \\
\hline $\begin{array}{l}\text { My child goes to the library } \\
\text { regularly }\end{array}$ & Not-at-risk $>$ at-risk $\left(\chi^{2}=8.319, \mathrm{df}=1, p=0.00\right)$ \\
\hline $\begin{array}{l}\text { In his/her leisure time my child } \\
\text { watches television }\end{array}$ & $\begin{array}{l}\text { No significant statistical differences between not-at } \\
\text { risk and at-risk pupils }\end{array}$ \\
\hline $\begin{array}{l}\text { In his/her leisure time my child } \\
\text { reads books }\end{array}$ & Not-at-risk $>$ at-risk $\left(\chi^{2}=24.582, \mathrm{df}=1, p=0.00\right)$ \\
\hline $\begin{array}{l}\text { In his/her leisure time my child } \\
\text { meets his/her friends }\end{array}$ & $\begin{array}{l}\text { No significant statistical differences between not-at } \\
\text { risk and at-risk pupils }\end{array}$ \\
\hline $\begin{array}{l}\text { In his/her leisure time my child } \\
\text { does sports }\end{array}$ & $\begin{array}{l}\text { No significant statistical differences between not-at } \\
\text { risk and at-risk pupils }\end{array}$ \\
\hline $\begin{array}{l}\text { In his/her leisure time my child } \\
\text { meets his/her boy/girlfriend }\end{array}$ & Not-at-risk $<$ at-risk $\left(\chi^{2}=9.363, \mathrm{df}=1, p=0.00\right)$ \\
\hline
\end{tabular}

Note: ${ }^{\mathrm{a}} 0=$ no, $1=$ yes. 
environment that enjoys and cultivates the use of cultural resources, particularly those that have an influence upon their all-round development and not only upon their academic attainment. Having a computer at home connected to the Internet, as well as the child reading books at home for leisure, might be associated with less risk for these children's school career. Even regular visits to the library could introduce a significant difference in the cultural capital that children take to school. These findings confirm the hypothesis formulated for this dimension regarding pupils at risk of dropping out, and might point to the need to stimulate these pupils' cultural and intellectual habits at home, as these may be associated with learning and school success.

\section{Parental involvement in their children's school progress}

In this dimension, parents were asked to indicate the degree to which they agreed on several statements regarding whether: the children have an adequate study atmosphere at home; they, as parents, need to know strategies to help their children at home; the children's school activity is a frequent cause of problems at home; the children face consequences when academic results are poor; there is a common agreement on values and norms in terms of the children's school progress; and the children are responsible for their own school progress.

The descriptive analysis showed that most surveyed parents $(87.8 \%)$ claimed to maintain good conditions to help their children with homework regarding time and family circumstances. Thus, parents have defined this environment as associated both with good spatial-physical conditions and emotional stability and with the absence of conflicts. Moreover, $95.4 \%$ of the parents appeared to buy all the school materials their children need: text and reading books, exercise books, encyclopaedias, dictionaries, and so forth. These findings confirm that most parents in the total sample try to provide their children, as much as possible, with all the resources they need in order to support their learning and adaptation to the school.

Also, most of them $(90.8 \%)$ admitted that they talk with their children about their everyday school life: about issues related to their academic progress, homework, examinations, teachers' interactions, and so forth. This finding may indicate that most parents are aware of the fact that it is important to communicate with their children regularly and that this constitutes a valuable motivation source when facing learning difficulties. Similarly, $87 \%$ of the parents consider that they show their affection to their children. The open expression of feelings together with daily dialogue are key strategies to stimulate the building up of an adequate self-esteem in children, especially when the child may already have a low self-conception associated with poor academic results. These findings might suggest that most parents realise the positive effects of such stimulation, which may facilitate their educational task regarding their children, thus encouraging a more satisfactory relationship with one another.

Nonetheless, more than one-half of the surveyed parents stated a lack of knowledge as to how to support their children's academic learning at home.

Moreover, this descriptive analysis (an independent-samples $t$-test comparative one) was conducted to evaluate the hypothesis that parents of pupils at risk of dropping out and parents of those who are not differ significantly in their behaviours and perceptions regarding the issues stated in this dimension (mean of at-risk group minus mean of not-atrisk group).

The analysis showed that there are significant statistical differences between parents of at risk pupils compared with their counterparts in a number of issues investigated. As 
shown in Table 2, parents of at-risk pupils claimed significantly more than parents of notat-risk pupils do that they lack strategies for effectively following up their teenagers' tasks at home, to frequently experience problems at home due to their children's school activity and to apply consequences to them when their academic results are poor.

On their part, the parents of not-at-risk pupils stated more than the parents of pupils atrisk did that their homes provide an adequate study atmosphere for their children, that they maintain common family agreements on values and norms relevant to their children's progress, and that they place responsibility for school progress on the children themselves.

These findings might suggest that parents of at-risk pupils are more likely to face difficulties and be less effective in monitoring their children's school activities at home than their counterparts are. At the same time, the strategies they use at home to check their children's work seem to differ from those of parents whose children are not at risk. It appears they concentrate more on their children facing consequences for poor academic results and for causing 'problems' at home, while the latter focus more on establishing family norms and values, and on placing the overall responsibility for academic progress on the children themselves. In this way, these results confirm the hypothesis formulated regarding this dimension.

\section{Parental academic expectations for their children}

In this dimension the following parental academic expectations for their children were analysed: to complete compulsory secondary school education level; to continue education after compulsory education; to attend vocational school; to reach a better

Table 2. Parents' involvement in children's education.

\begin{tabular}{|c|c|c|c|c|c|c|c|}
\hline $\begin{array}{l}\text { Please mark one choice each } \\
\text { time to show to what extent } \\
\text { the following practices are } \\
\text { used in the case of your } \\
\text { family? }\end{array}$ & Parent group & $n$ & $\operatorname{Mean}^{\mathrm{a}}$ & $\mathrm{SD}$ & $t^{\mathrm{b}}$ & df & $p$ \\
\hline \multirow{2}{*}{$\begin{array}{l}\text { My child has an adequate study } \\
\text { atmosphere at home }\end{array}$} & At-risk & 70 & 3.43 & 0.74 & -2.77 & 190 & 0.00 \\
\hline & Not-at & & 122 & 3.66 & 0.61 & & \\
\hline \multirow[t]{2}{*}{$\begin{array}{l}\text { I need to know strategies to help } \\
\text { my child at home }\end{array}$} & At-risk & 70 & 3.26 & 0.88 & 4.93 & 184 & 0.00 \\
\hline & Not-at-1 & & 116 & 2.68 & 0.94 & & \\
\hline \multirow[t]{2}{*}{$\begin{array}{l}\text { My child's school activity is a } \\
\text { frequent cause of problems at } \\
\text { home }\end{array}$} & At-risk & 70 & 2.69 & 1.07 & 7.62 & 190 & 0.00 \\
\hline & Not-at-r & & 12 & 1.79 & 0.91 & & \\
\hline \multirow[t]{2}{*}{$\begin{array}{l}\text { When academic results are poor, } \\
\text { my child faces consequences }\end{array}$} & At-risk & 68 & 2.44 & 0.91 & 3.09 & 183 & 0.00 \\
\hline & Not-a & & 117 & 2.01 & 0.92 & & \\
\hline \multirow[t]{2}{*}{$\begin{array}{l}\text { There is a common agreement } \\
\text { on values and norms in terms } \\
\text { of the child's school progress }\end{array}$} & At-risk & 70 & 3.15 & 0.83 & -4.01 & 188 & 0.00 \\
\hline & Not-at-r & & 120 & 3.52 & 0.57 & & \\
\hline \multirow{2}{*}{$\begin{array}{l}\text { My child is responsible for his/ } \\
\text { her own school progress }\end{array}$} & At-risk & 65 & 3.02 & 0.75 & -2.37 & 183 & 0.01 \\
\hline & Not-at-risk & & 120 & 3.29 & 0.76 & & \\
\hline
\end{tabular}

Note: ${ }^{\text {a }} 1=$ 'I totally disagree' to $4=$ 'I totally agree'. ' ${ }^{\mathrm{b}}$ Mean of at-risk group minus mean of not-at-risk group. 
education than theirs; and to get a better job than theirs. The hypothesis for this dimension was that parents of children not at risk of dropping out have higher academic expectation for their children than their counterparts.

Even though most respondents claimed setting high academic expectations for their children, parents of pupils at risk of dropping out compared with those of not-at-risk pupils differed significantly in all topic-items analysed; except in the more general statements 'I want my child to have a better job than mine' and 'I want my child to have a better education than mine' (mean $=3.62$, standard deviation $[\mathrm{SD}]=0.70$; mean $=3.70$, $\mathrm{SD}=0.49$, respectively). As Table 3 shows, parents of not-at-risk pupils tended to set higher expectations than their counterparts for their children to complete secondary school education and then continue their studies, whereas the parents of at-risk pupils seemed to expect their children to take up vocational studies to a higher extent than the former, possibly for securing their children a job immediately after completing compulsory education. These results confirm the aforementioned hypothesis for this dimension.

It appears that families of potential drop-outs consider that their children struggle to achieve academically, so they expect them to receive practical training that will allow them to enter the labour market more easily. It might also be inferred that these parents are satisfied if their children reach an educational level higher than theirs, because they expect that it could provide them with better opportunities as well as better working conditions.

\section{Parental contacts with the school}

Traditionally, parents' contacts with school are mainly motivated by discussing children's school achievement or misbehaviour. The hypothesis under study for this dimension is that parents of children at risk of dropping out visit the school more often and also discuss their children's problems with teachers more regularly than their counterparts do.

Both samples of parents claimed to contact their children's school frequently: $76.4 \%$ of the surveyed parents claimed so, either on their own initiative or because they were asked to do so. Most times, family-school interactions take place regarding negative incidents in relation to children's poor academic achievement or misbehaviour. No significant statistical differences were found between parents with children at risk and

Table 3. Parental academic expectations.

\begin{tabular}{|c|c|c|c|c|c|c|c|}
\hline $\begin{array}{l}\text { Please mark one choice each } \\
\text { time to show to what extent the } \\
\text { following practices are used in } \\
\text { the case of your family? }\end{array}$ & Parent group & $n$ & $\operatorname{Mean}^{\mathrm{a}}$ & SD & $t^{\mathrm{b}}$ & df & $p$ \\
\hline \multirow{2}{*}{$\begin{array}{l}\text { I expect my child to complete } \\
\text { compulsory high school level }\end{array}$} & At-risk & 70 & 3.10 & 0.91 & -9.32 & 188 & 0.00 \\
\hline & Not-a & & 120 & 3.90 & 0.37 & & \\
\hline \multirow{2}{*}{$\begin{array}{l}\text { I expect my child to continue } \\
\text { education after compulsory } \\
\text { high school level }\end{array}$} & At-risk & 69 & 2.69 & 0.88 & -11.62 & 187 & 0.00 \\
\hline & Not-at-risk & & 120 & 3.73 & 0.48 & & \\
\hline \multirow{2}{*}{$\begin{array}{l}\text { I expect my child to complete } \\
\text { technical school }\end{array}$} & At-risk & 69 & 2.99 & 0.92 & 9.149 & 168 & 0.00 \\
\hline & Not-at-risk & & 101 & 1.94 & 0.82 & & \\
\hline
\end{tabular}

Note: ${ }^{\text {a }} 1=$ 'I totally disagree' to $4=$ 'I totally agree'. ' Mean of at-risk group minus mean of not-at-risk group. 
those whose children were not, which suggest that this practice applies to most parents in the sample. Thus, this does not confirm the hypothesis formulated for this dimension.

Also, $89.3 \%$ of the total sample of parents said that they feel comfortable and welcome by the teachers when talking to them. This is a notable finding taking into account that, most times, parents contact the school to talk about negative issues regarding their children and that the experience parents have from their contacts with the school may influence their motivation to keep attending when needed in order to discuss matters affecting their children.

Nonetheless, the two samples appeared to differ in some other aspects of their contacts with the teachers and the school (Table 4). It was found that when teachers/schools initiate a contact or briefing with parents in order to inform them about positive aspects of their children, it is more likely $(t=-3.04, \mathrm{df}=181, p=0.00)$ that these parents are the ones whose children are not potential drop-outs $($ mean $=2.92, \mathrm{SD}=0.86)$ rather than parents of students at risk (mean $=2.59, \mathrm{SD}=0.84)$.

Moreover, the parents whose children are not at risk tend to initiate contacts with the school themselves in order to talk about positive aspects of their children's school life (mean $=3.02, \mathrm{SD}=0.83$ ) more often than parents whose children are at risk (mean $=2.62, \mathrm{SD}=0.96$ ); these differences have resulted to be statistically significant $(t=-3.54, \mathrm{df}=180, p=0.00)$.

Although most parents appeared interested in participating in school activities and felt comfortable at school, those who have at-risk children claimed that they do so less often than the others because they have not been invited to join in. Parents of at-risk children also reported home responsibilities as an obstacle for participating more often than parents whose children are not at risk. Table 5 shows the respective statistic findings.

\section{Discussion and conclusions}

The European Commission Eurostat Report on 'Education and Training for 2020' indicates that, at present, the average rate of school drop-out of the European Union countries is $14.1 \%$. The causes for this phenomenon might be associated with, among other factors, the school system itself, the teaching methods, the social-environmental factors and the family dynamics (Barr \& Knowles, 1986; Coleman, 1988; Rumberger, 2004; South et al., 2003). The reproduction of social class theory of Bourdieu and Passeron (1990) has been considered in this study as a framework that might contribute to explain the drop-out phenomenon. According to this theory, social capital serves to the creation of human capital through education; however, the power and ideology embedded in education and its

Table 4. Parental contacts with the school.

\begin{tabular}{|c|c|c|c|c|c|c|c|}
\hline $\begin{array}{l}\text { Please mark one choice each time to show } \\
\text { to what extent the following practices are } \\
\text { used in the case of your family? }\end{array}$ & Parent group & $n$ & Mean $^{\mathrm{a}}$ & $\mathrm{SD}$ & $t^{\mathrm{b}}$ & Df & $p$ \\
\hline \multirow{2}{*}{$\begin{array}{l}\text { The teachers/the school inform me about } \\
\text { positive aspects of my child }\end{array}$} & At-risk & 69 & 2.59 & 0.84 & -3.04 & 181 & 0.00 \\
\hline & Not-at-risk & & 114 & 2.92 & 0.86 & & \\
\hline \multirow{2}{*}{$\begin{array}{l}\text { I contact the teachers/the school to talk } \\
\text { about positive aspects of my child }\end{array}$} & At-risk & 68 & 2.62 & 0.96 & -3.54 & 180 & 0.00 \\
\hline & Not-at-risk & & 114 & 3.02 & 0.83 & & \\
\hline
\end{tabular}

Note: ${ }^{\text {a }} 1=$ 'I totally disagree' to $4=$ 'I totally agree'. ' ${ }^{\mathrm{b}}$ Mean of at-risk group minus mean of not-at-risk group. 
Table 5. Parental barriers to participate in school activities.

\begin{tabular}{|c|c|c|c|c|c|c|c|}
\hline $\begin{array}{l}\text { Please mark one choice each time to show } \\
\text { to what extent the following practices } \\
\text { are used in the case of your family? }\end{array}$ & $\begin{array}{l}\text { Parent demographic } \\
\text { group }\end{array}$ & $n$ & Mean $^{\mathrm{a}}$ & SD & $t^{\mathrm{b}}$ & df & $p$ \\
\hline \multirow{2}{*}{$\begin{array}{l}\text { In the cases I do not participate in the } \\
\text { school activities it is because of my } \\
\text { home responsibilities }\end{array}$} & At-risk & 67 & 2.25 & 1.14 & -2.83 & 185 & 0.00 \\
\hline & Not- & & 118 & 2.63 & & & \\
\hline \multirow{2}{*}{$\begin{array}{l}\text { I do not participate in the school activities } \\
\text { because the teachers/the school do not } \\
\text { ask me to }\end{array}$} & At-risk & 69 & 2.55 & 1.12 & 3.36 & 182 & 0.00 \\
\hline & Not-at-risk & & 113 & 2.10 & 0.96 & & \\
\hline
\end{tabular}

Note: ${ }^{\text {a }} 1=$ 'I totally disagree' to $4=$ 'I totally agree'. ' Mean of at-risk group minus mean of not-at-risk group.

practices leads to cultural and social inequalities that are reproduced by social classes. Empirical evidence of this theory has been shown by research; among other authors, Marjoribanks $(2002,2003,2004)$ explored the relationships among families, schools, individual characteristics and young adults' school outcomes.

The study presented in this paper shows that most parents of children at risk of dropping out have low educational background compared with those whose children are not at risk. This might influence the extent to which these families can provide their children with the so-called 'home capital' (Coleman, 1988, 1997; Marjoribanks, 2002; Symeou, 2007); that is, a home with social and cultural conditions able to support children's cultural, intellectual and social development as this is anticipated by the school system. The low educational standards of most of the parents of children at risk of dropping out participating in this study might well have conditioned their abilities and strategies to help their children at home with school matters. These findings are coherent with other international ones, such as those pointed out by Lareau (2000), Marjoribanks (2003), Martínez-González, MartínezÁlvarez, and Pérez-Herrero (2004), as well as with local findings (see for instance Symeou, 2009). These authors highlight the value of promoting social capital through effective collaboration among community groups and institutions - like family-school cooperation - in order to prevent and control social phenomena, such as school absenteeism and school failure. Cooper, Robinson, and Patall (2006), Dannesboe, Kryger, Palludan, and Ravn (2010), Deslandes (2009), Forsberg (2007), Oubrayrie-Roussel and Safont-Mottay (2011), Safont-Mottay, Oubrayrie-Roussel, Rousseau, and Deslandes (2008) offered the same suggestion after carrying out qualitative or quantitative studies with primary and secondary school students.

International studies on dropping out of high school show the difficulty of identifying the causes of this phenomenon (Fredricks et al., 2004), suggesting school-related and nonschool-related factors. The study presented in this paper focused on non-school-related factors, such as the family and 'the curriculum of the home', which according to international studies might influence children's school performance (Deslandes, 2001; Redding, 2000; Symeou, 2005). The curriculum of the home includes, among other issues, family attributions, expectations, beliefs, and parental abilities to support children's development. This approach to the drop-out phenomenon has not been much considered in past studies, thus efforts in this paper concentrated on identifying indicators of family circumstances, educational practices, aspirations and school involvement of parents whose children are at risk of dropping out of school compared with those of parents whose children are not at risk. These indicators might help schools and other stakeholders support 
parents in creating more effective academic-related family dynamics to prevent their teenagers from dropping out of school.

The findings presented in this paper show a wide range of differences in the circumstances, resources, expectations, perceptions and practices of families whose children are potential droppers and those whose children are not. These findings are coherent with Rumberger's (2001) concept that the drop-out phenomenon cannot be explained by considering only the individual pupils' characteristics (Anderson et al., 2002). Pupils' interacting contexts have also much to say, especially the family microsystem and the mesosystem included in Bronfenbrenner's (1979) ecology model. The findings of this study also indicate that schools should show interest in identifying the circumstances and needs families face in order to be effectively involved in their children's education, so as to provide them with some support for enhancing their children's development and school success. Epstein (2011), Hiatt-Michael (2001) and Martínez-González et al. (2005) addressed this matter. On the other hand, Collins and Laursen (2004) and Chen and Kaplan (2003) also claimed that, through school support, families can learn positive parenting practices, techniques and strategies that could be particularly useful to those with at-risk pupils.

In this study, indicators of individual-cultural differences between children at risk and not at risk of dropping out are associated with their habits to read, to go to the library and to watch television. All of them can be connected with family dynamics, expectations and routines, which show how 'family social capital' serves to the creation of different 'human capital' through education. Compared with those of their counterparts, this study shows that the reading habits of children at risk of dropping out are restricted mainly to compulsory reading activities assigned by the school. Also, these teenagers seem to prefer watching television in their leisure time than reading books or going to the library; however, their counterparts present these characteristics to a lower degree. Consequently, the findings suggest that schools might advise parents of teenagers at risk of dropping out on both the need to control the time their children watch television at home and on effective strategies to stimulate reading. This seems imperative according to Nippold, Duthie, and Larsen (2005) who claim that interest in reading declines with age (11-15 years). As for our research, it was found that the most popular teenagers' free-time activities were listening to music, watching television or videos, playing sports, and playing computer or videogames. These preferences can have both positive and negative impact on children's literacy development and school success, thus adding on the risk of dropping out of school. Moses (2008) reported this impact through a review of the television-viewing literature in the USA.

Considering that interest in reading declines with age and that this might have an impact on the risk of dropping out of school, Sainsbury and Schagen (2004) found that attitudes to reading are higher at age nine than at age 11. Similar findings were reached by McKenna, Ellsworth, and Kear (1995) when exploring children's attitudes toward reading. On the other hand, Payne, Whitehurst, and Angell (1994) claimed that the home literacy environment plays a key role in the development of language ability in preschool children from low-income homes; as stated before, these low-income homes are more likely to have children at risk of dropping out. As regards parental academic expectations for their children, most parents participating in this study indicated that they would like their children to achieve higher educational and professional level than those of their own. Nevertheless, consistent with previous research (Behnke, Piercy, \& Diversi, 2004; Chen, \& Kaplan, 2003; Hao \& Bonstead-Bruns, 1998; Marjoribanks, 2002), parental educational expectations were associated with their children's academic achievement. Parents of pupils at risk of dropping out seem to expect their children to take up vocational studies more often than their counterparts do, which will allow them to enter the labour market earlier. 
This may indicate that these children were performing at the level their parents expected of them, or maybe that their parents accommodate their expectations to their children's academic achievement. Thus it is critical to expect children to achieve at the very best of their abilities, trying not to underestimate their academic abilities. This applies to parents, but also to teachers and other significant caregivers in children's lives, who have an influence on their self-concept and expectations for themselves to succeed. However, this may prove difficult for children who do not have confidence in their abilities to achieve. As Trusty and Pirtle (1998) claimed, a clear implication for schools is to attend to a child's academic self-concept by assisting both children and parents to improve expectations of academic achievement and perceptions of children's capabilities. Therefore, parents should expect high achievement from their children, communicate these expectations to them, and be involved in their education; by doing so, children will understand that their parents believe in their abilities. In short, it is important that parents and teachers maintain high educational expectations of all children, particularly for those who are often stereotyped as less academically capable.

Despite the fact that in this study most parents of potential drop-out pupils have a low educational background, these parents seem to get involved in their children's education in different ways, thus trying to compensate for the limited academic help they can offer. This involvement might relate to talking with their children about daily school life, to provide them with the appropriate study resources, to show them their affection, to create for them the right home environment to study, to encourage them when they come across difficulties in certain subjects or when they fail. In most cases, parents of at-risk pupils provide them with good studying conditions at home (a study room, books, even a computer and Internet connection), but many of them lack effective strategies to stimulate their children to study and to support them with homework. These results point out the value of the 'curriculum of the home' and are consistent with previous results from Marjoribanks (1987), MartínezGonzález and Corral-Blanco (1991), Paik (2004) and Symeou (2007), which point to the high interest most parents show towards their children's academic progress, independently of their social, professional or income level.

Given that most parents, including those of pupils at risk of dropping out, are doing their best to help their children with school matters, it seems that there is a need to promote effective school-family-community collaboration in order to support the parents and the teachers to urge children to become responsible for their own tasks. The theoretical positions of Bourdieu (1998) and Coleman (1997) of cultural and social capital, respectively, suggest viewing school-family interactions as activations of cultural and social capital that explain how pupils and their families manage their schooling. Findings from this research show that parent-teacher meetings are mainly focused on discussing negative aspects of the children, such as poor school achievement or misbehaviour. The same tendency was reported previously too (Davies \& Johnson, 1996; Hiatt-Michael, 2001; Symeou, 2003). This leads to consider both the convenience of increasing the type and quality of school-family-community partnership (Simon \& Epstein, 2001) and of improving the quality of teacher-parent meetings (Symeou, Roussounidou, \& Michaelides, 2012). In order to achieve these aims, teacher training on school-family partnerships and communication skills is needed, aiming at helping teachers to obtain a better understanding and collaboration with parents and families for the benefit of children. This positive effect is possible, especially if we take into account the finding that most families feel welcome at the school, as this study showed, even in spite of the difficulties those parents of pupils at risk of dropping out might face. This is critical to promote effective teacher-parent interactions. 


\section{Implications and recommendations for practice}

In addition to the conclusions and implications already mentioned in the previous section, there are some other implications and several educational recommendations that may be suggested in order to provide an answer to the socio-educational needs of the families with potential droppers.

The study sheds light on the need that families with low educational levels face in order to act at home in a way that prevents their children from dropping out. First, it seems that there is a need to promote effective communication skills in parents, teachers and children so that they are able to interact in an appropriate and stimulating way. The findings of this paper also indicate the need to provide parents with useful information about studying skills so as to better follow up their children's homework. Encouraging children to read is recommended in order to stimulate their reading habits and comprehension strategies so as to be able to put them into practice when studying.

As far as parent-teacher meetings are concerned, it seems necessary to focus more frequently on the positive intellectual and attitudinal characteristics of the children as a way to facilitate both communication between them and taking decisions together about how to proceed with children at risk. Problems and difficulties regarding children are the main reasons for parents and teachers to work together, and particularly when referring to children at risk of dropping out. Thus, it would be useful to create opportunities at school for parents and teachers to meet in order to discuss positive aspects of children at risk as well. These opportunities would help both parents and teachers to build up a more relaxed atmosphere for effective communication, for decision-making and problem-solving. They would also help parents and teachers to support each other in the development of their respective educational responsibilities with children at risk. Holding these meetings would also stimulate the self-esteem of children at risk. Schools could possibly organise activities to inform parents about effective strategies to follow-up their teenagers' homework and to promote effective communication between parents and children, so that parents can encourage them to do their best. As Davies and Johnson (1996, p. 91) noted: 'The better informed parents are about the schools and their special programs, the better able they will be to participate effectively. Access to information enables parents to successfully support children's learning'.

Finally, more cross-cultural studies on the phenomenon of pupils' dropping out of schools and parental involvement in their education should be carried out. This will increase knowledge on this subject by comparing families' and schools' practices and needs according to the different histories, cultures and contexts of the educational systems involved. Policy-makers and educational administrators could then use these results to take effective decisions to improve the educational conditions of the contexts in which children develop and to prevent educational and social problems from arising.

\section{Acknowledgements}

The study was conducted as part of the activities of the European Project Drop-Out Open-Door (112578-CP-1-2003-1-NL-COMENIUS-C21), funded by the European Commission. Views expressed in this article do not reflect the views of the European Commission. We would like to thank especially Ms Eleni Roussounidou who participated in the project on behalf of the Cyprus consortium and was actively involved in all activities of the project.

\section{Note}

1. For the purposes of this study, any reference to education in Cyprus applies to the Greek-Cypriot educational system. 


\section{Notes on contributors}

Loizos Symeou is assistant professor in sociology of education at the European University Cyprus. His areas of interest and publications are in the sociological investigation of school parent-child relationships and how these link to cultural and social capital. Recent work includes a study on homework, and a European project on the school experience of Roma families.

Raquel-Amaya Martínez-González is professor of education at Oviedo University (Spain). She is the coordinator of both the research team on "Socio-Educative Assessment and Intervention in Families, Schools and Communities' and the "Observatory on Family-School-Social Agents Partnerships", both at Oviedo University, Spain. She was visiting fellow at the Australian Institute of Family Studies in Melbourne. She received the Spanish National Research Award in Education and the "José Lorca" Award (Asturias, Spain) for her work on promoting children's rights. She was president of the European Research Network About Parents in Education (ERNAPE, www.ernape.net). She is a member of the Council of the European Education Research Association (EERA, http://www.eera-ecer.de/), representing the Spanish Educational Research Association (AIDIPE, http://www.uv.es/aidipe).

Lucía Álvarez-Blanco is member of both the research team on "Socioeducative Assesment and Intervention in Families, Schools and Communities" and "The Observatory on Family-SchoolCommunitiy Partnership", at the Department of Educational Sciencies, Oviedo University (Spain). She is author and coauthor of national and international books, book chapters and journal articles. She received the Spanish National Research Award on Family Education by the Spanish Foundation on Family Actions.

\section{References}

Anderson, G.E., Whipple, A.D., \& Jimerson, S.R. (2002). Grade retention: Achievement and mental health outcomes. Bethesda, MD: National Association of School Psychologists.

Barr, R.B., \& Knowles, G.W. (1986). The San Diego city schools 1984-1985. School learner and high school program participation attitude study. San Diego, CA: San Diego Pubic School, Planning \& Research Division (ERIC Document Reproduction Service No. ED 274767).

Behnke, A.O., Piercy, K.W., \& Diversi, M. (2004). Educational and occupational aspirations of Latino youth and their parents. Hispanic Journal of Behavioral Sciences, 26(1), 16-35.

Bishop, J. (1988). Vocational education for at-risk youth: How can it be made effective? (Working Paper 88-11). Ithaca, NY: School of Industrial \& Labor Relations at Cornell University (ERIC Document Reproduction Service No. ED 987150).

Bourdieu, P. (1998). Practical reason: On the theory of action. Stanford, California: Stanford University Press.

Bourdieu, P., \& Passeron, J.C. (1990). Reproduction in education, society and culture (2nd ed.). London: Sage.

Bronfenbrenner, U. (1979). The ecology of human development. Cambridge, MA: Harvard University Press.

Bull, K.S., \& Garrett, M. (1989). At-risk in rural America: Strategies for education. Education Considerations, 17(1), 44-47.

Bull, K.S., Salyer, B.K., \& Montgomery, D.L. (1990). ACRES at-risk task force: Drop out survey. Paper presented at the 10th Annual Conference of the American Council for Rural Special Education, Tucson, AZ. March 18-23, 1990.

Carbonaro, W.J. (1998). A little help from my friend's parents: Intergenerational closure and educational outcomes. Sociology of Education, 71, 295-313.

Chen, Z.-Y., \& Kaplan, H.B. (2003). School failure in early adolescence and status attainment in middle adulthood: A longitudinal study. Sociology of Education, 76, 110-127.

Coleman, J.S. (1988). Social capital in the creation of human capita.l. American Journal of Sociology, 94(Supplement), 94-120.

Coleman, J.S. (1997). Family, school, and social capital. In L.J. Saha (Ed.), International encyclopedia of the sociology of education (pp. 623-625). Oxford: Pergamon.

Coleman, J.S., Campbell, E.Q., McPartland, J., Mood, A.M., Weinfeld, D., \& York, R.L. (1966). Equality of educational opportunity. Washington, DC: US Government Printing Office.

Coley, R.J. (1995). Dreams deferred: High school drop-outs in the United States. Princeton, NJ: Educational Testing Service, Policy Information Center. 
Collins, W.A., \& Laursen, B. (2004). Parent-adolescent relationships and influences. In R. Lerner \& L. Steinberg (Eds.), Handbook of adolescent psychology (pp. 331-361). New York: John Wiley $\&$ Sons.

Comerford, D.J., \& Jacobson, M.G. (1987). Suspension - 'Capital punishment for misdemeanours': The use of suspension at four suburban junior high schools and viable alternatives that could work. Paper presented at the Annual Meeting of the American Educational Research Association, Washington, DC (ERIC Document Reproduction Service No. ED 287196). 1987, April 20-24.

Cooper, H., Robinson, C.J., \& Patall, E.A. (2006). Does homework improve academic achievement? A synthesis of research, 1987-2003. Review of Educational Research, 76(1), 1-62.

Crozier, G. (2000). Parents and schools: Partners or protagonists? Stoke on Trent: Trentham Books.

Cyprus Pedagogical Institute. (2002). Report on drop-out figures in Cyprus. Nicosia: Cyprus Pedagogical Institute.

Dannesboe, K.I., Kryger, N., Palludan, C., \& Ravn, B. (2010). The social world of children's homework. International Journal About Parents in Education, 4(1), 11-22.

Davies, D., \& Johnson, V. (1996). Crossing boundaries: Community-family-schools partnerships. Forum of Education, 51(1), 83-91.

Deslandes, R. (2001). A vision of home-school partnership: Three complementary conceptual frameworks. In F. Smith, K. Van Der Wolf, \& P. Sleegers (Eds.), A bridge to the future. Collaboration between parents, schools and communities (pp. 11-23). Nijmegen: ITS.

Deslandes, R. (2009). International perspectives on student outcomes and homework: Familyschool-community partnerships. London: Taylor \& Francis.

Dunham, R.G., \& Alpert, G.P. (1987). Keeping juvenile delinquents in schools: A prediction model. Adolescence, 22, 45-57.

Ediger, M. (1987). School dropouts: Absenteeism and tardiness. Kirksville, MO: Northeast Missouri State University (ERIC Document Reproduction Service No. ED 279941).

Ekstrom, R.B., Goertz, M.E., Pollack, M.J., \& Rock, D.A. (1986). Who drops out of high school and why? Findings from a national study. Teacher's College Record, 87(3), 356-373.

Epstein, J.L. (2011). School, family, and community partnerships: Preparing educators and improving schools. Boulder, CO: Westview Press.

European Commission Directorate General for Education and Culture. (2005). Study on access to education and training, basic skills and early school leavers (Ref. DG EAC 38/04). Lot 3: Early school leavers. Final report. Brussels: European Commission.

Eutostat (2005). Labour force survey. Retrieved from http://epp.eurostat.ec.europa.eu.

Forsberg, L. (2007). Homework as serious family business: Power and subjectivity in negotiations about school assignments in Swedish Families. British Journal of Sociology of Education, 28(2), $209-222$.

Fredricks, J.A., Blumenfeld, P.C., \& Paris, A.H. (2004). School engagement: Potential of the concept, state of the evidence. Review of Educational Research, 74, 59-109.

Goldschmidt, P., \& Wang, J. (1999). When can schools affect dropout behaviour? A longitudinal multilevel analysis. American Educational Research Journal, 34, 395-419.

Granic, I., Dishion, T.J., \& Hollesntein, T. (2003). The family ecology of adolescence: A dynamic systems perspective on normative development. In R. Adams \& M.D. Berzonsky (Eds.), Blackwell handbook of adolescence (pp. 60-91). Malden, MA: Blackwell Publishers.

Hao, L., \& Bonstead-Bruns, M. (1998). Parent-child differences in educational expectations and the academic achievement of immigrant and native students. Sociology of Education, 71, 175-198.

Hartford Public Schools (1987). Hartford community plan for dropout reduction. Hartford, CT: Hartford Public Schools. (ERIC Document Reproduction Service No. ED).

Helge, D. (1990). A national study regarding at-risk students. Bellingham, WA: National Rural Development Institute, Western Washington University.

Hiatt-Michael, D.B. (2001). Home-school communication. In D.B. Hiatt-Michael (Ed.), Promising practices for family involvement in schools (pp. 39-57). Greenwich, CT: Information Age Publishing.

Janosz, M., Archambault, I., Morizot, J., \& Pagani, L.S. (2008). School engagement trajectories and their differential predictive relations to dropout. Journal of Social Issues, 64(1), 21-40.

Kagan, D. (1990). How schools alienate students at risk: A model for examining proximal classroom variables. Educational Psychologist, 25(2), 105-125. 
Lan, W., \& Lanthier, R. (2003). Changes in students' academic performance and perceptions of school and self before dropping out of schools. Journal of Education for Students Placed at Risk, 8(3), 309-333.

Lareau, A. (2000). Home advantage: Social class and parental intervention in elementary education. Lanham, MD: Rowman \& Littlefield Publishers.

Lee, V.E., \& Burkam, D.T. (2003). Dropping out of high school: The role of school organization and structure. American Educational Research Journal, 40(2), 353-393.

Levy, S. (1987). Investing in the health of at-risk youth: School-based health clinics in the south. Research Triangle Park, NC: Southern Youth Policies Board (ERIC Document Reproduction Service No. ED 290826).

Marjoribanks, K. (1987). Ability and attitudes correlates of academic achievement: Family-group differences. Journal of Educational Psychology, 79(2), 171-178.

Marjoribanks, K. (2002). Family and school capital: Towards a context theory of students' school outcomes. Dordrecht: Kluwer Academic.

Marjoribanks, K. (2003). Family and ability correlates of academic achievement: Social status group differences. Psychological Reports, 93, 419-422.

Marjoribanks, K. (2004). Families, schools, individual characteristics and young adults' outcomes: Social and cultural group differences [R.-A. Martínez-González \& S. Paik (Guest Eds.), International perspectives on families, schools, and communities: Educational implications for partnership. Special issue]. International Journal of Educational Research, 41(1), 10-23.

Martínez-González, R.A., \& Corral-Blanco, N. (1991). Parents and children: Academic values and school achievement. International Journal of Educational Research, 15(2), 163-169.

Martínez-González, R.A., Martínez-Álvarez, R., \& Pérez-Herrero, H. (2004). Children's school assessment: Implications for family-school partnerships. International Journal of Educational Research, 41(1), 24-38.

Martínez-González, R.A., Pérez-Herrero, M.H., \& Rodríguez-Ruiz, B. (Eds.) (2005). Familyschool-community partnerships merging into social development. Oviedo (Spain): SM Publishing Group.

Martínez-González, R.A., Pérez-Herrero, M.H., Álvarez-Blanco, L., \& García-González, M.P. (2009). Observatory on family-school-community partnership in Spain. A longitudinal programme to promote quality in education and social development. In R. Deslandes (Ed.), International perspectives on contexts, communities and evaluated innovative practices. Family-school-community partnerships (pp. 110-125). New York: Routledge, Taylor \& Francis Group.

McKenna, M.C., Ellsworth, R.A., \& Kear, D.J. (1995). Children's attitudes toward reading: A national survey. Reading Research Quarterly, 30, 934-956.

Mensch, B.S., \& Kendel, D.B. (1988). Dropping-out of high school and drug involvement. New York: Columbia University (ERIC Document Reproduction Service No. ED 296041).

Moses, A.M. (2008). Impacts of television viewing on young children's literacy development in the USA: A review of the literature. Journal of Early Childhood Literacy, 8, 67-102.

National Research Council. (2001). Understanding dropouts: Statistics, strategies, and high-stakes testing. Washington, DC: Committee on Educational Excellence and Testing Equity, National Academy Press.

Nippold, M.A., Duthie, J.K., \& Larsen, J. (2005). Literacy as a leisure activity: Free-time preferences of older children and young adolescents. Language, Speech, and Hearing Services in Schools, $36,93-102$.

Oubrayrie-Roussel, N., \& Safont-Mottay, C. (2011). Adolescent homework management strategies and perceptions of parental involvement. International Journal about Parents in Education, 5 (2), $78-85$.

Paik, S. (2004). Korean and US Families, schools and learning. International Journal of Educational Research, 41(1), 71-90.

Payne, A.C., Whitehurst, G.J., \& Angell, A.L. (1994). The role of the home literacy environment in the development of language ability in preschool children from low-income homes. Early Childhood Research Quarterly, 9, 427-440.

Persianis, P. (1981). The political and economical factors as the main determinants of educational policy in independent Cyprus (1960-1970). Nicosia: Cyprus Pedagogical Institute.

Phtiaka, H. (1998). 'It's their job, not ours!': Home-school relations in Cyprus. Mediterranean Journal of Educational Studies, 3(2), 19-51. 
Raffe, D. (1986). Unemployment and school motivation: The case of truancy. Education Review, 38 (1), $11-19$.

Reay, D. (1998). Class work: Mothers' involvement in their children's primary schooling. London: UCL Press.

Redding, S. (2000). Parents and learning (Educational Practices Series. International Bureau of Education in collaboration with International Academy of Education, 2). Geneva: UNESCO, Retrieved from http://www.ibe.unesco.org.

Rumberger, R.W. (1987). High school dropouts: A review of issues and evidence. Review of Educational Research, 57, 101-121.

Rumberger, R.W. (1995). Dropping-out of middle school: A multilevel analysis of students and schools. American Educational Research Journal, 32, 583-625.

Rumberger, R.W. (2001, January 13). Why students drop out of school and what can be done. Paper presented at the Drop Outs in America: How Severe is the Problem? What do we Know about Intervention and Prevention? Conference, Harvard University, Cambridge, MA.

Rumberger, R.W. (2004). Why students drop out of school. In G. Orfield (Ed.), Dropout in America (pp. 131-155). Cambridge, MA: Harvard Educational Press.

Rumberger, R.W., \& Larson, K.A. (1998). Student mobility and the increased risk of high school drop out. American Journal of Education, 107, 1-35.

Safont-Mottay, C., Oubrayrie-Roussel, N., Rousseau, M., \& Deslandes, R. (2008, 24-28 March). Parents and homework at the secondary level in France and in Quebec, Paper presented at the Roundtable: Partnerships for Secondary Students: Navigating the Worlds of School, Family, and Community. Annual Meeting of the American Educational Research Association, New York.

Sainsbury, M., \& Schagen, I. (2004). Attitudes to reading at ages nine and eleven. Journal of Research in Reading, 27, 373-386.

Schutz, E.W, Tules, R., Rice, W.K., Brauer, I., \& Harvey, J. (1986). The association of student drop out rates with student attributes, Paper presented at the Annual Meeting of the American Educational Research Association, San Francisco, CA (ERIC Document Reproduction Service No. ED 071). 1986, April 16-20.

Simon, B.S., \& Epstein, J.L. (2001). School-family and community partnerships. Linking theory to practice. In D.B. Hiatt-Michael (Ed.), Promising practices for family involvement in schools (pp. 1-24). Greenwich, CT: Information Age Publishing.

Smetana, J., \& Daddis, C. (2002). Domain-specific antecedents of parental psychological control and monitoring: The role of parenting beliefs and practices. Child Development, 73(2), 563-580.

South, S.J., Baumer, E.P., \& Lutz, A. (2003). Interpreting community effects on youth educational attainment. Youth \& Society, 35(1), 3-36.

Statistical Service of Cyprus. (2012). Cyprus in the EU scale. Nicosia: Press and Information Office.

Steinberg, L. (2001). We know some things: Adolescent-parent relationships in retrospect and prospect. Journal of Research on Adolescence, 11, 1-19.

Steinberg, L., \& Silk, J.S. (2002). Parenting adolescents. In M.H. Bornstein (Ed.), Handbook of parenting (Vol. 1): Children and parenting (pp. 103-113). Mahwah, NJ: Lawrence Erlbaum.

Swanson, C.B., \& Schneider, B. (1999). Students on the move: Residential educational mobility in America's schools. Sociology of Education, 72, 54-67.

Symeou, L. (2002). Present and future home-school relations in Cyprus: An investigation of teachers' and parents' perspectives. The School Community Journal, 12(2), 7-34.

Symeou, L. (2003). Family-school communication: Critically revisiting parent-teacher briefings. In S. Castelli, M. Mendel, \& B. Ravn (Eds.), School, family, and community partnerships in a world of differences and changes (pp. 119-134). Gdansk: University of Gdansk.

Symeou, L. (2005). Past and present in the notion of school-family collaboration. Aula Abierta, 85, $165-184$.

Symeou, L. (2007). Cultural capital and family involvement in children's education: Tales from two primary schools in Cyprus. British Journal of Sociology of Education, 28(4), 473-487.

Symeou, L. (2009). Mind the gap! Greek-Cypriot parents and their children's homework. In R. Deslandes (Ed.), International perspectives on student outcomes and homework: Familyschool-community partnerships (pp. 76-94). London: Taylor \& Francis.

Symeou, L. (2010). Teacher-family communication in Cypriot primary schools. A multiple case study of state Greek-Cypriot primary schools. Beau Bassin: VDM Publishing House. 
Symeou, L., Roussounidou, E., \& Michaelides, M. (2012). 'I feel much more confident now to communicate with parents': An evaluation of in-service training on teacher-parent communication. The School Community Journal, 22(1), 65-88.

Trusty, J., \& Pirtle, T. (1998). Parents' transmission of educational goals to their adolescent children. Journal of Research and Development in Education, 32(1), 53-65.

Weber, J.M., \& Sechler, J.A. (1988). Vocational education and the retention of at-risk youth. Columbus, OH: National Center for Research in Vocational Education, The Ohio State University (ERIC Document Reproduction Service No. ED 297123).

Wehlage, G.G., \& Rutter, R.A. (1986). Dropping out: How much do schools contribute to the problem? Teachers College Record, 87, 374-392.

Wheelock, A. (1986). Dropping out: What the research says. Equity and Choice, 3(1), 7-11.

Widmann, J.C., \& Hoidsen, T.M. (1988). A study of students who drop out of the San Juan district. San Jose, CA: Jose United School District (ERIC Document Reproduction Service No. ED 298411). 